\title{
3110 モーションシミュレータを使用した乗心地の事前予測
}

\author{
Prediction of Train Ride Comfort Using a Motion Simulator
}

\author{
正 林 哲也( $\mathrm{J}$ R 東海)
}

Tetsuya HAYASHI, Central Japan Railway Company, 1545-33, Oh-yama, Komaki, Aichi, Japan

\begin{abstract}
This paper presents the method for prediction of train ride comfort using a motion simulator that can reproduce the acceleration same as actual train with high precision. The motion simulator used in this study can produce not only the acceleration of actual train but also that analyzed virtually with computer simulation. We can evaluate train ride comfort with body sense before the route of rail track is designed using this method. Two track profiles with several curves are compared from the point of view of train ride comfort experimentally. One profile is designed observing former law and another is designed with exception. The results show both of them have no problem about ride comfort.
\end{abstract}

Key Words: Railway Vehicle, Motion Simulator, Train Ride Comfort, Prediction

\section{1.はじめに}

著者らはこれまで、鉄道車両の乗心地を実験室内で体感 評価することのできるモーションシミュレータ、「車両運 動総合シミュレータ」(以下シミュレータと呼ぶ)を開発し 1)、快適性に関する様々な実験を行ってきた ${ }^{23) 34}$ 。

本シミュレータは実際の車雨で測定された加速度(前後、 左右、上下）等を忠実に再現することや、実車の運動デー 夕を加工して様々な走行条件が変わった場合の乗心地を体 験することなどができる。このため、複数日に渡って実施 された走行試験の乗心地を比較する、多くの被験者を実際 に武験列車に乗せることなく評価に参加させることで母数 の多い試験結果が得られる、といった特長を生かした取り 組みが行われてきた。

ところで本装置はまた、実測された運動データを使用す るだけでなく、計算上で求められた車雨の運動を再現する ことも可能である。本稿ではそうした取り組みの一例を紹 介する。

\section{2。計算結果による乗心地評価}

2.1 対象とする現象

旧省令（新幹線鉄道構造規則）では、軌道に曲線を設け る際には、最小円曲線長や曲線と曲線の間に設ける最小直 線長が規定されていたが、新省令（鉄道技術基準省令）で はこれらに関する規定がなく、事業者の判断によって軌道 の線形を設計することができる。

実際に線形を決めるにあたっては、乘心地の他に、周辺 の地形や既存設備との関係、コストなどを総合的に判断す ることとなるが、そのためには上記の各項目についてどの ような設計が望ましいかに関する情報が必要となる。これ らの項目の中で、乗心地は事前の評洒が難しいもののひと つである。その理由は、評価を人閒の感覚にたよる部分が ある一方で、様々な軌道の線形における乗心地を実際に比
較することは実際問題として困難であったからである。 従来であれば省令に従った設計を行っていれば、現実問 題として、乘心地に関して大きな不都合が生じることは考 えにくかった。しかしながら、規制が緩和され事業者の判 断による設計が許されるようになった時、その良し悪しも 事業者自身で判断することが必要となってくる。

Table 1 Provisions of old and new Law

\begin{tabular}{|c|c|c|}
\hline & $\begin{array}{l}\text { 新幹線鉄道構造規 } \\
\text { 則 (旧省令) }\end{array}$ & $\begin{array}{l}\text { 鉄道に関する技術上 } \\
\text { の基隻を定める省令 } \\
\text { (新省令) }\end{array}$ \\
\hline $\begin{array}{l}\text { 緩和曲線長 } \\
\text { 超過遠心力の時間 } \\
\text { 的変化割合 }\end{array}$ & $0.0075 \mathrm{Cd} \cdot \mathrm{V}$ & 規定なし \\
\hline $\begin{array}{l}\text { 緩和曲線長 } \\
\text { カント変化量の時 } \\
\text { 間的変化割合 }\end{array}$ & $0.0062 \mathrm{Cm} \cdot \mathrm{V}$ & 規定なし \\
\hline $\begin{array}{l}\text { 緩和曲線長 } \\
\text { 脱線に対する安全 }\end{array}$ & $0.3 \mathrm{Cm}$ & $\begin{array}{l}0.45 \mathrm{Cm} \text { (解积基淮に } \\
\tau \text { ) }\end{array}$ \\
\hline 最小円曲線長 & $\begin{array}{l}\text { 100m以上。やむをえ } \\
\text { ない場合は } 0 \mathrm{~m} \text { 。 }\end{array}$ & 規定なし \\
\hline $\begin{array}{l}\text { 曲線間の最小直線 } \\
\text { 長 }\end{array}$ & $\begin{array}{l}\text { 100m以上。やむむをえ } \\
\text { ない場合は0m。 }\end{array}$ & 規定なし \\
\hline
\end{tabular}

$\mathrm{Cm}$ ：カント量、 $\mathrm{Cd}$ ：カント不足量、 $\mathrm{V}$ : 速度

\section{2 解析結果}

乗心地を事前に予測する手段の一つとして、計算機上で 車両の運動をシミュレーションし、車体に発生する加速度 を求めることが従来から存在する。ここでは代表的な車両 運動解析ソフトである”VAMPIRE”を使用した。車両モデ ルはFig.1 に示す通りで、各種パラメータには実際の車両 のものを使用した。

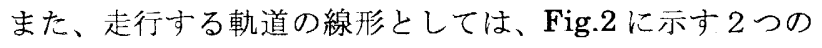

[No.05-52］日本機械学会第 14 回交通・物流部門大会講演論文集 [2005-12.7～9. 川崎 ] 
案を用意した。ここで Case 0 とは旧省令に準拠した場合 である。Case 1 は Case 0 と同一の地点に敷設することを 前提に、円曲線長を $0 \mathrm{~m}$ 、曲線と曲線の間の直線の長さも 0m としたものである。

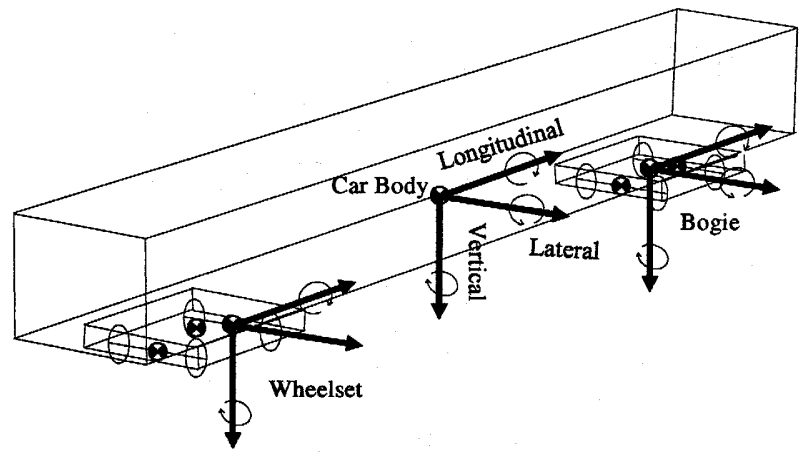

Fig.1 the Model of a Car

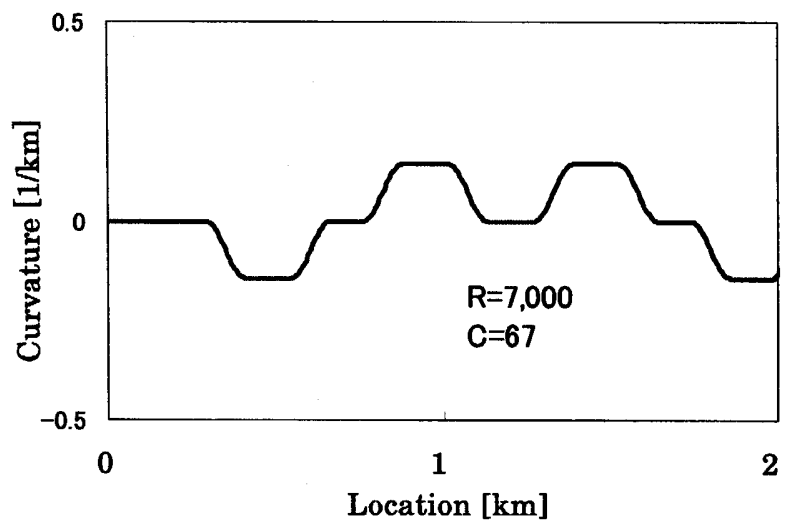

(a) Route of Case 0

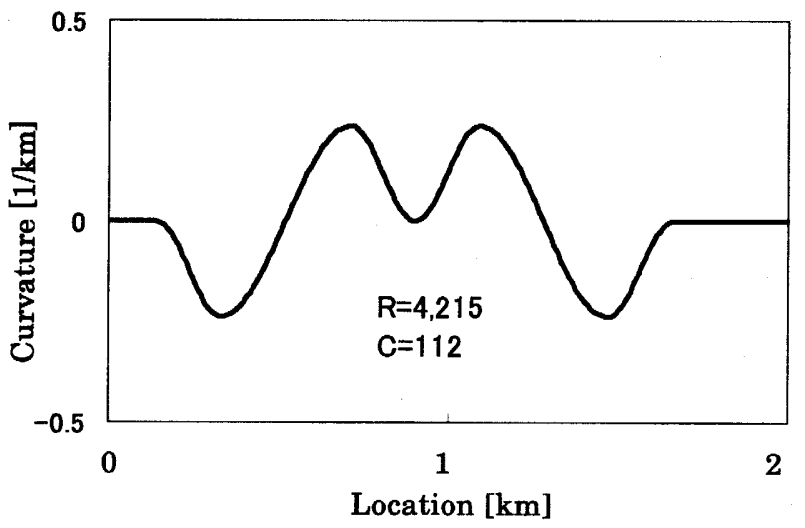

(b) Route of Case 1

Fig.2 Profile of each Case

Table 2 Features of each Case

\begin{tabular}{|c|c|c|c|}
\cline { 2 - 4 } \multicolumn{1}{c|}{} & $\begin{array}{c}\text { Minimum Length of a } \\
\text { Transition Curve }\end{array}$ & $\begin{array}{c}\text { Minimum Length of a } \\
\text { Circular Curve }\end{array}$ & $\begin{array}{c}\text { Minimum Length of a } \\
\text { Straight Section } \\
\text { between Curves }\end{array}$ \\
\hline Case 0 & 0 & 0 & 0 \\
\hline Case 1 & 0 & $\Delta$ & $\Delta$ \\
\hline
\end{tabular}

$O$ : Observing former Law

$\triangle$ : Observing former Law with Exception

上記の条件で解析を行った結果を示したのが Fig.3,Fig.4 である。ここでは平面の線形を比較することを
目的としているので、左右方向の加速度とロール角速度に 着目した。

これらの図からわかるように、Case 0 においては左右加 速度のピーク值は小さいが、加速度変化の頻度は多い。一 方、Case 1 では加速度変化の頻度は少ないが、左右加速度 のピーク值は大きく、一概にどちらが優れているかを波形 のみから判断するのは難しいという結果が得られた。

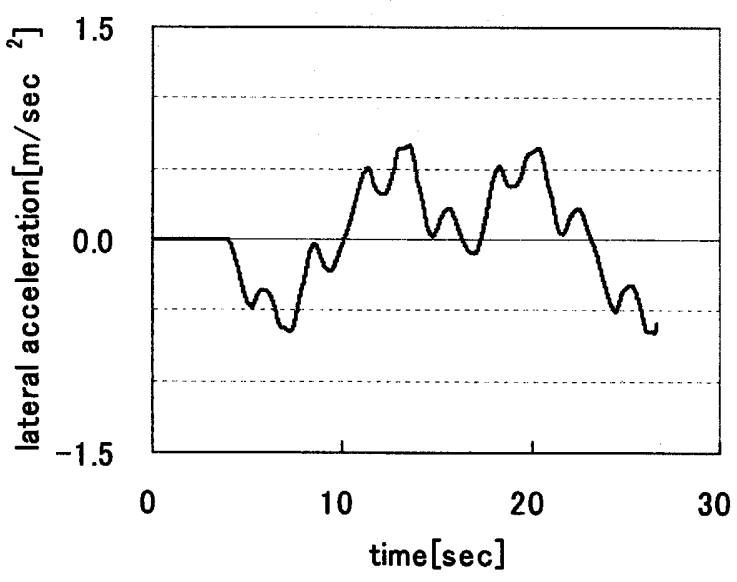

(a) Case 0

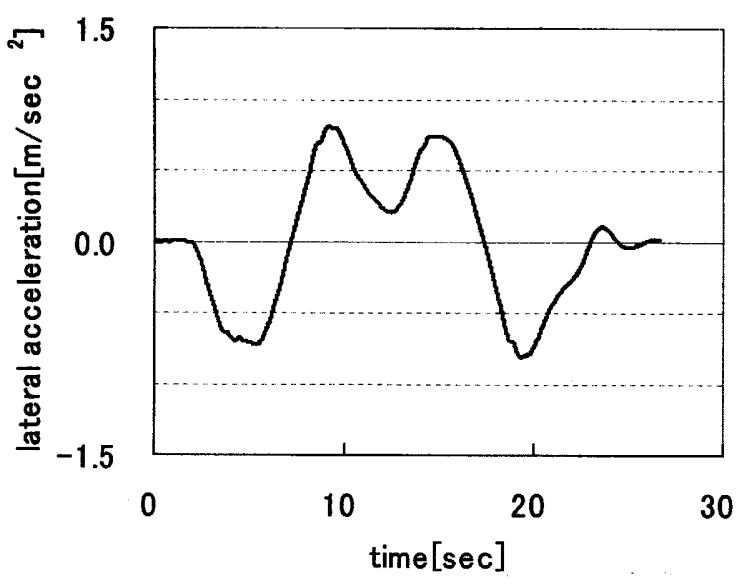

(b) Case 1

Fig.3 Result of Analysis (Lateral Acceleration)

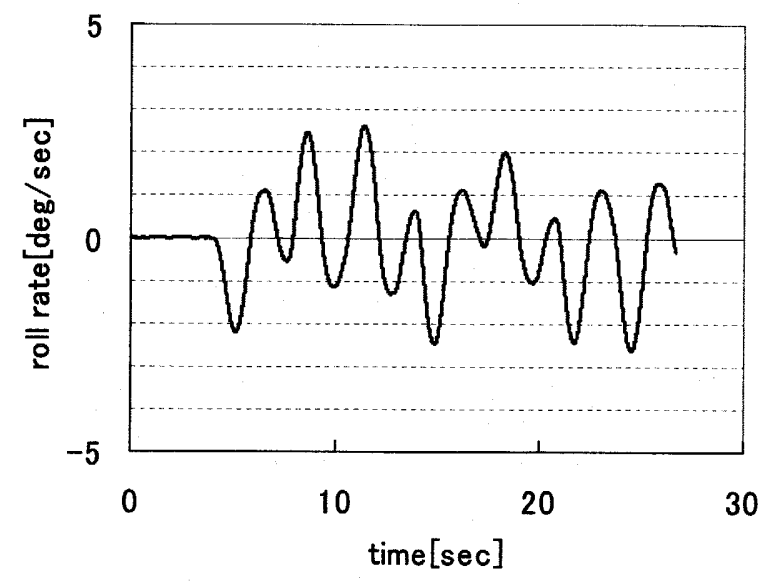

(a) Case 0 


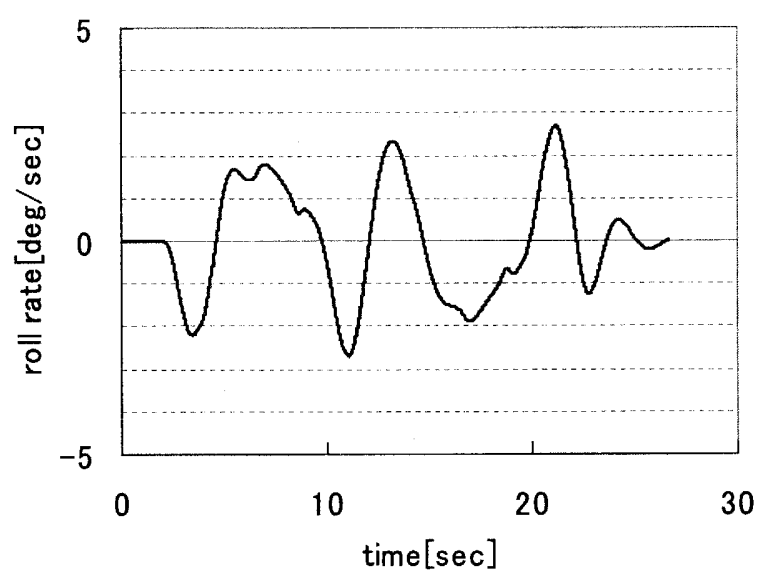

(b) Case 1

Fig.4 Result of Analysis (Roll Rate)

3.シミュレータによる運動再現

3.1 解析結果のシミュレータへの適用

冒頭で述べたシミュレータは動摇発生機構として 3 つの 装置を備えており、それぞれ次のような自由度を持つため 装置全体としては 10 自由度の動作となる。すなわち、(1) 直線モーション装置：1 自由度（左右）、(2) 6 軸モーショ ン装置：6 自由度（前後、左右、上下、ロール、ピッチ、 ヨ一)、(3)高周波振動台: 3 自由度 (前後、左右、上下) となり、これらはそれぞれの装置の持つ周波数特性に応じ て使い分けられる。

一方、前章で行った解析は左右加速度とロール角速度の 2 つが意味を持つデータとなっている。そこで、この 2 自 由度のデータをシミュレータ人適用する。ただしここで注 意が必要なのは、解析結果とシミュレータの制御信号では 座標系が異なることである。解析結果においては、左右加 速度は乗客に作用する加速度、すなわち床面に平行に座標 軸を採った場合の值となっている。また、ロール角は水平 面に対するロール角である。

一方、シミュレータの制御信号は直線モーション装置と 6 軸モーション装置については、実験室床面を基準とした 座標となっている。また、高周波振動台はシミェレータの 模擬客室を基準とした座標系である。そこで解析結果を制 御信号に変換する際には、以下のような計算を行った。

(1)ロール角速度については積分し、ロール角として 6 軸モ ーション装置の制御信号とした。

(2)左右加速度については、2 回積分し直線モーション装置 の制御信号とした。ただし解析結果はロール方向の傾斜に よって生じる重力の床面に平行な成分を含んでいるため、

この分を考慮した。すなわち直線モーション装置で発生す べき左右方向の加速度 $\mathrm{a}_{\mathrm{y} 1}$ は

$\mathrm{a}_{\mathrm{y} 1}=\mathrm{a}_{\mathrm{ys}}-\mathrm{g} \cdot \sin \phi_{\mathrm{s}}$

$\mathrm{a}_{\mathrm{ys}}$ : シミュレーション結果による左右方向加速度

$\phi_{s}:$ シミュレーション結果によるロール角

$\mathrm{g}:$ 重力加速度

となるように補正している。

以上により、シミュレータを使用して Case 0 と Case 1 の 2 つの条件を体感によって比較することが可能となった。
3.2 実車データの付加によるリアル感の向上

前節までで解析によって求めた運動をシミュレータによ って再現することは可能となったが、シミュレーション結 果には、モデルを作成する際に考慮に入れなかった事項は 反映されていない。このため、軌道狂いによる振動や車体 の曲げ振動など、振動的な動きが表現されておらず、実車 とは異なった印象の体感となる。そこでシミュレータで発 生する 10 自由度の運動のうち、解析結果を用いる 2 自由 度を除いた残りの 8 自由度については、実車が直線区間を 等速で走行した際の実測データを付加した。これにより、 曲線の線形の違いによる乗心地の差は、解析結果により表 現され、実車同様の臨場感は実車データにより表現される 制御データを用意することができた。

Fig.5 に実車で計測された振動データとシミュレータで 再現された振動データの周波数成分を比較したものを示す。 この図から、1 $\mathrm{Hz}$ から $40 \mathrm{~Hz}$ にかけての振動成分は実車と シミュレータで同等であることがわかる。なお、低周波成 分については、直線走行と曲線走行の違いの影響により、 両者は合致しない。また、 $40 \mathrm{~Hz}$ 以上の高周波成分につい ては、本シミュレータのスペックを越えるため再現されな いが、これ以上の周波数帯域は、乗心地評価にはあまり寄 与しないことが知られている。

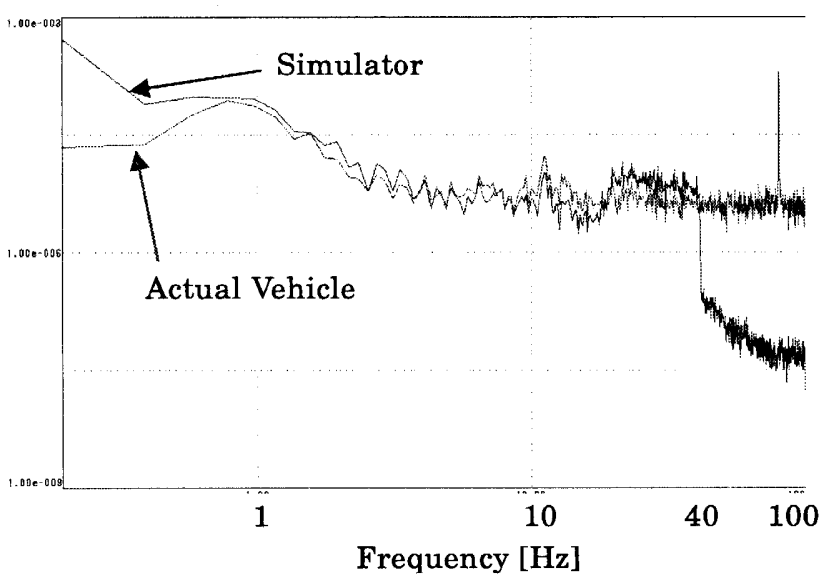

Fig.5 Power Spectral Density of Lateral Acceleration

\section{4. 線形の違いによる乗心地の比較実験}

4.1 実験手法

2 章で述べた 2 通りの線形が乗心地に与える影響を調べ るため、3 章で述べた手法により 2 通りのシミュレータ用 制御データを用意した。試験順序としてはこれに直線走行 の条件を加えた 3 通りの条件を、Table 3 の順に実施した。

Table 3 Order of theTest

\begin{tabular}{|c|c|c|c|c|}
\hline \multicolumn{2}{|c|}{ Order } & Condition & Posture & Purpose \\
\hline \multirow{2}{*}{ Practice } & Straight & Sitting & Remember Ordinary Ride Comfort \\
\cline { 2 - 4 } & Case 0 & Sitting & Experience Testing Method \\
\hline \multirow{2}{*}{ Test 1} & 1st & Case 1 & Standing & Compare in a Standing Posture \\
\cline { 2 - 4 } & 2nd & Case 0 & Standing & \\
\hline \multirow{2}{*}{ Test 2 } & 1st & Case 1 & Sitting & Compare in a Sitting Posture \\
\hline
\end{tabular}

すなわち始めに直線走行の振動を与え、被験者に対象とす る線区における代表的な車種の乗心地を提示する。次に、 Case 0 の条件を提示し、今回評価の対象とする現象がどの ようなものかについて慣れさせる。以上をもって練習とし た。次いで、試番 1 として立位での Case 1 と Case 0 の比 
較を、試番 2 として座位での Case 1 と Case 0 の比較を行 った。

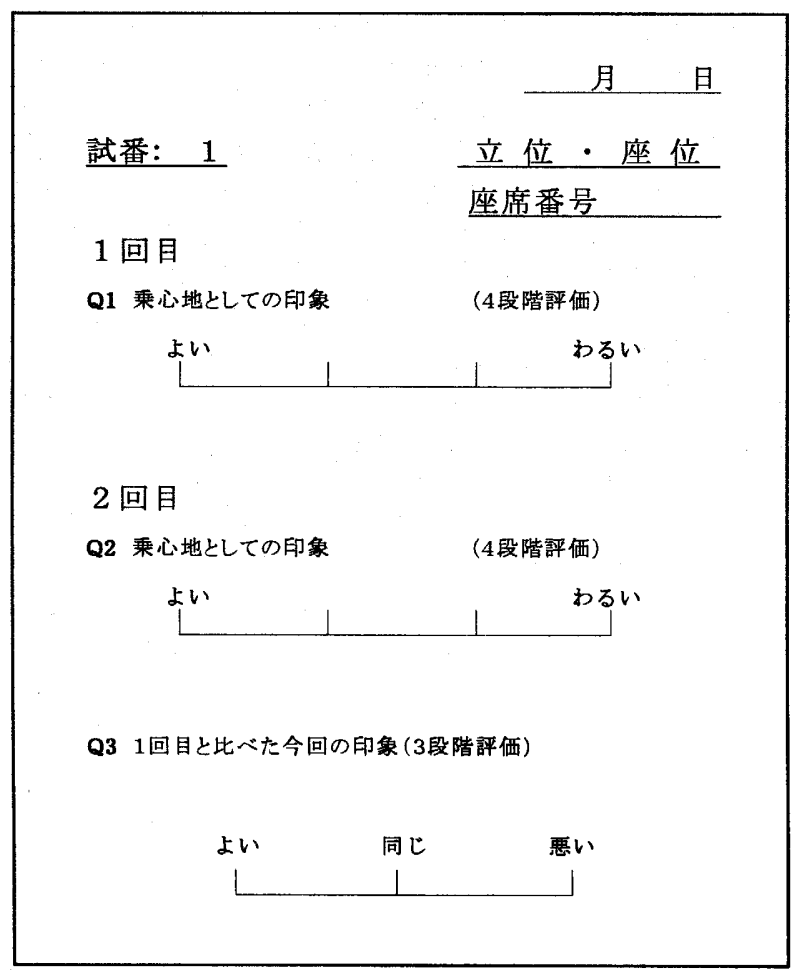

Fig.6 Questionnaire Sheet

回答は Fig.6 のような用紙を用い、それぞれの試番につ いて、1回目(Case 1:ただし被験者には教示していない) では乗心地の印象を 4 段階評価で回答させた。次いで、2 回目 (Case 0：同じく教示してない) では、1回目と同様 の 4 段階評価での印象に加えて、1 回目との比較を「よい」 「同じ」「悪い」の 3 段階の評価で回答させた。

\section{2 実験結果}

Fig7に Q3 に対する回答を集計した結果を示す。この図 から、今回比較の対象とした軌道の線形の違いによる乗心 地については、総じて優劣のつけ難い結果であることがわ かる。被験者からの事後の聞き取りでは、加速度のピーク 值が小さい Case 0 を好む者と、加速度変化の頻度が少な いCase 1 を好む者で、評価が分かれる傾向がみられた。 また、姿勢別では、座位では Case 0 の評価がよく、立位 では比較的 Case 1 の評価がよい。

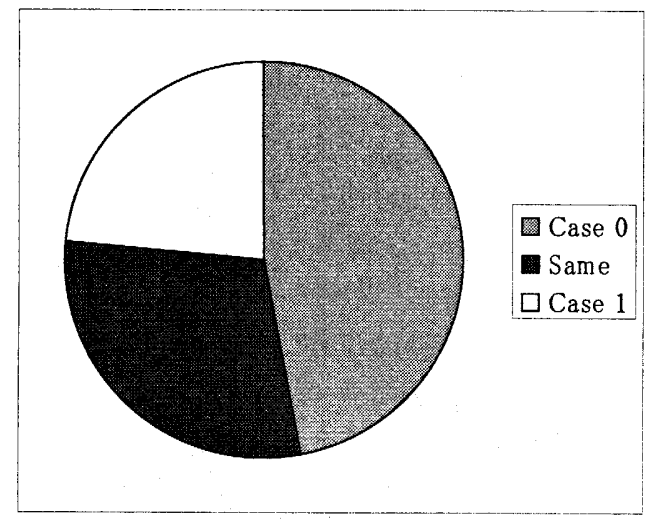

(a) Sitting

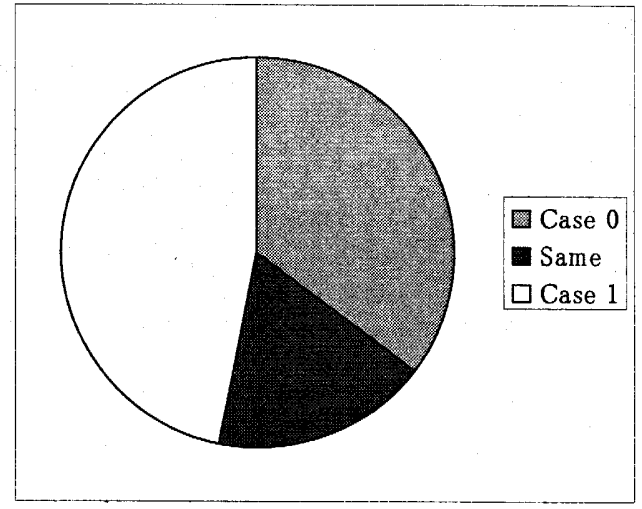

(b) Standing

Fig.7 Answer to Q.3 "Which is better?"

以上の結果から、乗心地に関して Case 0 と Case 1 の体 感上の差は、個人によって判断が分かれる程度のものであ り、線区全体でみた場合に必ずしも乗心地が区間毎に均一 でないことを考慮すると、いずれの案でも乗心地の上では 差し支えないとの判断ができる。

5.まとめ

一旦敷設されてしまうと容易には変更できない軌道の線 形について、乗心地を事前に体感により評価することを目 的とし、計算上で求めた車両の運動をモーションシミュレ 一タを用いて比較する実験を実施した。その結果、線形の 違いが乗心地に与える影響の程度を把握することが可能と なった。

このような検証を事前に行えば、事業者の判断で行う設 計の質的向上を図ることが可能となると考える。

\section{参考文献}

1) 林・坂上・森下・長澤・那須、鉄道車両運動総合シミュ レータの開発、2003 年度年次大会講演論文集 $(\mathrm{V}) 、$ 211-212

2) 森下・坂上・林、車両運動総合シミュレータによる曲線 通過時の乗心地指標の検討、第 10 回鉄道技術連合シン ポジウム講演論文集、129-132

3）林・平沢・金保・須田、モーションシミュレータを活用 した鉄道車両の快適性評価実験に関する考察、第 13 回 交通・物流部門大会講演論文集、215-216

4）須田・林・金保・平沢、鉄道車両の振動・動摇環境下に おける快適性評価に対するシミュレータ実験、第 9 回「運 動と振動の制御」シンポジウム講演論文集、164-167 